\title{
HUKUM BADAN USAHA YANG DAPAT DIDIRIKAN OLEH YAYASAN UNTUK MEWUJUDKAN KEMUDAHAN IKLIM BERUSAHA DI INDONESIA
}

\author{
Kasiani; Fakultas Hukum Universitas Islam Balitar, Jl. Mojopahit No. 12A, Blitar, Jawa Timur; \\ E-mail: yanikasiani@gmail.com
}

\begin{abstract}
Abstrak
Sebagai subyek hukum natural person, Undang-Undang Yayasan mengatur bahwa Yayasan dapat menjalankan kegiatan usaha sebagai sarana untuk menunjang Yayasan dalam menjalankan maksud dan tujuannya, namun undang-undang tidak menjelaskan bentuk badan usaha apa yang dapat dijalankan oleh Yayasan, fakta di masyarakat suatu Yayasan mendirikan kegiatan usaha seperti kegiatan di bidang perternakan, perkebunan, pertokoan yang mana bentuk kegiatan tersebut layaknya kegiatan usaha perorangan, dengan menggunakan nama para organ Yayasan. Permasalahan dalam penelitian ini yaitu bentuk badan usaha apa yang dapat didirikan dan atau diikuti oleh Yayasan sebagai investor, serta bagaimana legalitas kepemilikan kegiatan usaha Yayasan yang didirikan atas nama organ Yayasan. Melalui penelitian normatif disimpulkan bahwa Pertama, bentuk badan usaha yang dapat didirikan dan atau diikuti oleh yayasan pada pekerkembangan pengaturan yang ada adalah berbentuk perseroan terbatas (PT), Koperasi dan bentuk-bentuk lain yang telah diatur dalam Undang-Undang yang dengan tegas menyatakan bahwa Yayasan merupakan badan penyelenggara dari kegiatan tersebut. Kedua, Yayasan tidak memiliki legalitas sebagai pemilik badan usaha dan legalitas kepemilikan ada pada nama organ Yayasan secara pribadi, sesuai nama yang tercantum di dalam akta pendirian badan usaha. Artinya meskipun kekayaan yang digunakan badan usaha seluruhnya adalah berasal dari kekayaan Yayasan, namun secara yuridis Yayasan tidak memiliki alas hukum bahwa badan usaha tersebut adalah milik Yayasan.
\end{abstract}

Kata Kunci: Badan Usaha, Yayasan, Kegiatan Usaha Yayasan

\section{Abstract}

As a natural person legal subject, the Law on Foundation regulates that foundations can carry out business activities as long as it means to support the Foundation in carrying out its aims and purpose, but the law does not explain what form of business entity a Foundation can run, the fact is that in society a Foundation establishes business activities such as activities in the field of livestock, plantations, shops, which are the forms of these activities like individual business activities, using the names of the organs of the Foundation. The research problem is what form of business entity can a foundation establish and / or participate in as an investor? And what is the legality of ownership of the foundation's business activities that are established on behalf of the foundation's organs? This type of research is normative research, namely research on legal principles, and descriptive analysis research that aims to describe the actual conditions in society about how foundations carry out business activities, from the results of the study it is concluded that First, the form of a business entity that can be established and/or followed by foundations in development, the existing regulations are in the form of a limited liability company (PT), cooperatives and other forms that have been regulated in a law which clearly states that the foundation is the organizing body for these activities. Second, the foundation does not have legality as the owner of a business entity and the legality of ownership is in the name of the Foundation organ personally, according to the name stated in the deed of establishment of the business entity. This means that even though the assets used by a business entity are entirely derived from the assets of the Foundation, legally the Foundation has no legal basis that the business entity belongs to the Foundation.

Keywords: Business Entities, Foundations, Foundation Business Activities 


\section{PENDAHULUAN}

\section{Latar Belakang}

Undang-Undang Republik Indonesia Nomor 16 Tahun 2001 tentang Yayasan jouncto Undang-Undang Republik Indonesia Nomor 28 Tahun 2004 tentang Perubahan Atas Undang-Undang Republik Indonesia Nomor 16 tahun 2001 tentang Yayasan (selanjutnya disebut UU Yayasan) dalam hukum nasional sebagai suatu norma yang menjabarkan dan Sebagai cermin dari kehendak yang tidak pernah berhenti dalam mewujudkan kesejahteraan serta kemakmuran bagi rakyat Indonesia dengan adil dan merata. Meskipun pada dasarnya mensejahterakan dan mencerdaskan kehidupan bangsa adalah peran pemerintah, sebagaimana hal tersebut merupakan landasan filosofi yaitu telah dirumuskan dalam Pancasila dan Pembukaan Undang-Undang Dasar Negara Republik Indonesia Tahun 1945 (UUD NRI 1945). ${ }^{1}$

Tujuan Yayasan adalah di bidang sosial, keagamaan, dan kemanusiaan, kegiatan tersebut antara lain meliputi kegiatan di bidang pendidikan, kesenian, hak asasi manusia, olah raga, perlindungan konsumen, lingkungan hidup, kesehatan dan ilmu pengetahuan. ${ }^{2}$ Bidang-bidang kegiatan Yayasan tersebut merupakan pengejawantahan beberapa Pasal di dalam UUD N RI Tahun 1945 yaitu Pasal 27 ayat (1) dan (2), Pasal 31 dan Pasal 34 ayat (1), (2) dan (3). ${ }^{3}$ Sehingga suatu nilai filosofis di dalam undang-undang Yayasan adalah sebagai sebuah kemutlakan.

Legalitas Yayasan sebagai badan hukum di tegas dalam Pasal 1 butir 1 UU No. 16 Tahun 2001 Tentang Yayasan, ${ }^{4}$ selain itu juga ditegaskan dalam Undang-Undang Republik Indonesia Nomor 17 Tahun 2013 tentang Organisasi Kemasyarakatan jo Undang-Undang Republik Indonesia Nomor 16 Tahun 2017 Tentang Penetapan Peraturan Pemerintah Pengganti Undang-Undang Nomor 2 Tahun 2017 Tentang Perubahan Atas Undang-undang Republik Indonesia Nomor 17 Tahun 2013 Tentang Organisasi Kemasyarakatan Menjadi Undang-Undang (selanjutnya disebut UU Ormas). Pada Pasal 9, Pasal 11 UU No. 17 Tahun 2013 Tentang Organisasi Kemasyarakatan. ${ }^{5}$

Sebagai organisasi yang didirikan dan dibentuk oleh masyarakat secara sukarela berdasar pada kesamaan aspirasi, kehendak, kebutuhan, kepentingan, kegiatan, dan tujuan untuk berpartisipasi dalam pembangunan demi tercapainya tujuan negara Kesatuan Republik Indonesia yang berdasar pada Pancasila. ${ }^{6}$ Yayasan sebagai salah satu

\footnotetext{
${ }^{1}$ Kasiani. (2019). Rekonsepsi Penggabungan Yayasan Pendidikan Tinggi dalam Perspektif UU RI No. 28 Tahun 2004 tentang Perubahan Atas UU RI Nomor 16 Tahun 2001 tentang Yayasan, Disertasi Program Doktor Ilmu Hukum Fakultas Hukum Universitas Brawijaya, h. 1

2 Penjelasan Pasal 8 UU RI No. 16 Tahun 2001 tentang Yayasan

${ }^{3}$ Pasal 27 Ayat (1) dan (2), Pasal 31, Pasal 34 UUD NRI Tahun 1945.

${ }^{4}$ Pasal 1 butir 1 UU No. 16 Tahun 2001 tentang Yayasan menegaskan bahwa "Yayasan adalah badan hukum yang terdiri atas kekayaan yang dipisahkan dan diperuntukkan untuk mencapai tujuan tertentu di bidang sosial, keagamaan, dan kemanusiaan, yang tidak mempunyai anggota". ${ }^{5}$ Pasal 9, menyatakan : "Ormas didirikan oleh 3 (tiga) warga negara indonesia atau lebih, kecuali ormas yang berbadan hukum Yayasan". jo Pasal 11 UU No. menyatakan bahwa "Ormas berbadan hukum sebagaimana dimaksud dalam Pasal 10 ayat (1) huruf a dapat berbentuk : a. perkumpulan, atau b. Yayasan."

${ }^{6}$ Pasal 1 Ayat (1) UU Ormas
} 
badan hukum memiliki peran dan fungsi dalam pembangunan berkonsekuensi untuk melaksanakan seluruh kaidah ormas, yakni sebagai organisasi nirlaba yang sehat, dijalankan secara demokratis, professional, mandiri, keterbukaan serta sebagai organisasi yang dijalankan dengan prinsip akuntabel. ${ }^{7}$

Bentuk untuk memberi kemandirian bagi Yayasan dalam mencapai maksud dan Tujuan Yayasan yang tidak lain adalah untuk mensejahterakan Masyarakat, maka oleh karenanya Pemerintah memberi kebijakan peluang kepada Yayasan untuk melakukan kegiatan usaha, dengan cara mendirikan badan usaha atau ikut serta dalam suatu kegiatan badan usaha. Kegiatan usaha yang dijalankan oleh Yayasan adalah kegiatan usaha yang memiliki kesesuaian dengan maksud dan tujuan didirikannya suatu Yayasan. Dan dalam undang-undang ini memberi penjelasan bahwa kegiatan usaha Yayasan memiliki cakupan luas dan dicontohkan antara lain di bidang hak azasi manusia, kesenian, olah raga, perlindunang konsumen, pendidikan, lingkungan hidup, kesehatan dan ilmu pengetahuan. Berdasarkan pada kegiatan yang dijalankan oleh Yayasan tersebut, maka sangat jelas bahwa kegiatan-kegiatan tersebut bertalian dengan kebutuhan dasar manusia. ${ }^{8}$

Berdasarkan pada uraian sebagaimana di atas, fungsi penting Yayasan teletak pada tugasnya sebagai badan penyelenggara kegiatan yang memiliki hubungan dengan pemenuhan kebutuhan dasar manusia artinya bahwa Yayasan memiliki tanggung jawab besar menjalankan kegiatan tersebut sebagaimana konsekuesi yang harus dilakukan oleh Yayasan sebagai organisasi nirlaba yang demokratis, professional, mandiri, transparan, dan akuntabel. Dengan lebih menitik beratkan pada aspek kemandirin Yayasan dalam menjalankan kegiatan mencapai maksud dan tujuan didirikannya Yayasan.

Aspek kemandirian menjadi kunci penting dalam suatu Yayasan, yang dimaksud kemandirian disini adalah suatu keadaan dimana dalam menjalankan kegiatanya memenuhi kebutuhan untuk mencapai maksud dan tujuan, Yayasan mampu dan tidak bergantung pada pihak lain. Dan untuk tujuan itulah para pebentuk undang-undang mengatur tentang sumber kekayaan Yayasan yang dapat diperoleh tidak hanya berasal dari sumbangan para donatur, wakaf, hibah, hibah wasiat, namun undang-undang ini juga mengatur kebolehan Yayasan untuk memperoleh sumber kekayaan dari hal-hal lain yang sifatnya tidak bertentangan dengan Anggaran Dasar Yayasan dan atau peraturan perundang-undangan yang berlaku di Indonesia, ${ }^{9}$ namun disayangkan pembuat undang-undang tidak menjelaskan tentang apa yang dimaksud perolehan lain yang diatur dalam Pasal 26 ayat (2) huruf "e", maka dengan demikian dapat diartikan bahwa Yayasan bisa mendirikan badan usaha apapun selama tidak keluar dari ketentuan yang ada dalam anggaran dasarnya dan tidak bertentangan dengan peraturan perundang undangan.

\footnotetext{
7 Pasal 4 UU Ormas

8 Penjelasan Pasal 8 UU No. 16 Tahun 2001 tentang Yayasan.

9 Pasal 26 ayat (2) UU RI No. 16 Tahun 2001 tentang Yayasan
} 


\section{Rumusan Masalah}

Perkembangan di masyarakat Yayasan mendirikan pertokoan, perbengkelan, perternakan, pertanian dan bidang-bidang lain dengan menggunakan nama salah seorang organ Yayasan. Berdasarkan pada fakta tersebut, maka sangat urgen untuk diteliti tentang bentuk badan usaha apa yang dapat didirikan oleh Yayasan dan atau diikuti oleh Yayasan sebagai investor ? Dan bagaimana legalitas kepemilikan kegiatan usaha Yayasan yang didirikan atas nama organ Yayasan?

\section{METODE PENELITIAN}

Penelitian ini merupakan penelitian ilmu hukum, dilakukan dengan menggunakan metode penelitian normatif, dengan jenis pendekatan yang digunakan pada penelitian ini adalah pendekatan perundang-undangan (statute approach). Dalam penelitian ini menggunakan sumber bahan hukum primer dan bahan hukum sekunder, dengan bahan hukum yang dikumpulkan dari teknik studi kepustakaan (library research) yang selanjutnya dianalisis oleh penulis dengan teknik deskripsi, sistematisasi, evaluasi dan pada akhirnya dengan menggunakan teknik argumentasi penulis untuk dapat ditarik suatu kesimpulan.

\section{PEMBAHASAN}

\section{A. Dasar Hukum Yayasan Menjalankan Kegiatan Usaha}

Pasal 3 ayat (1) UU Nomor 16 Tahun 2001 tentang Yayasan merupakan dasar hukum Yayasan dalam menjalankan kegiatan usaha dengan cara mendirikan suatu badan usaha. sebagaimana penegasan tersebut berbunyi sebagai berikut: "Yayasan dapat melakukan kegiatan usaha untuk mendukung pencapaian maksud dan tujuannya dengan cara mendirikan badan usaha dan/ikut serta dalam suatu badan usaha".10 Dan dalam penjelasan sebagaimana diatur dalam UU No. 28 Tahun 2004 Tentang Perubahan atas UU No. 16 Tahun 2001 Tentang Yayasan menjelaskan bahwa ketentuan ayat (1) dimaksud untuk mengaskan bahwa Yayasan tidak digunakan sebagai wadah usaha dan juga tidak untuk melakukan kegiatan usaha secara langsung, namun Yayasan dalam menjalankan kegiatan usaha tersebut dengan cara mendirikan suatu badan usaha lain dimana Yayasan mernyertakan kekayaan didalam badan usaha tersebut. ${ }^{11}$

Kegiatan usaha yang bisa dijalankan oleh Yayasan adalah kegiatan yang memiliki kesesuaian dengan maksud dan tujuan pendirian suatu Yayasan, hal ini di tegaskan dalam ketentuan Pasal 7 ayat (1) UU No. 16 Tahun 2001, selain itu undang-undang membatasi jumlah modal yang digunakan untuk penyertaan dalam badan usaha yaitu tidak lebih dari 25\% dari seluruh kekayaan yang dimiliki oleh Yayasan. ${ }^{12}$ Lebih lanjut pada Pasal 8 menegaskan bahwa kegiatan usaha dari badan usaha yang sesuai dengan maksud dan tujuan Yayasan serta tidak bertentangan dengan ketertiban umum,

\footnotetext{
${ }^{10}$ Pasal 3 ayat (1) UU No. 16 Tahun 2001 Tentang Yayasan.

11 Penjelasan Pasal 3 ayat (1) UU No. 28 Tahun 2004 Tentang Perubahan atas UU No. 16 Tahun 2001 Tentang Yayasan.

12 Pasal 7 ayat (1) dan (2) UU No. 16 Tahun 2001 Tentang Yayasan.
} 
kesusilaan, dan/atau peraturan perundang - undangan yang berlaku. Dan dalam penjelasannya menyatakan bahwa kegiatan usaha dari badan usaha yayasan mencakup antara lain HAM, kesenian, olah raga, perlindungan konsumen, pendidikan, lingkungan hidup, kesehatan dan ilmu pengetahuan.

Sebagaimana dasar hukum pengaturan Yayasan dalam kegiatan usaha sebagaimana diatas dapat disimpulkan batas-batas sebagai berikut : 1). Yayasan tidak boleh digunakan sebagai wadah melakukan kegiatan usaha. 2). Kegiatan usaha dilakukan diluar Yayasan dalam wadah usaha secara terpisah yakni dengan mendirikan badan usaha. 2). Yayasan dapat ikut serta dengan badan usaha lain di luar Yayasan. 3). Kegiatan usaha yang diikuti oleh Yayasan adalah yang bersifat prospektif. 4). Kekayaan yang digunakan dalam penyertaan kegiatan usaha tidak lebih dari 25\% dari seluruh kekayaan Yayasan.

Berdasarkan pada uraian diatas maka Yayasan dalam menjalankan kegiatan usaha yayasan dapat berperan atau berkedudukan sebagai :

a. Yayasan berkedudukan sebagai Pendiri Badan Usaha.

b. Yayasan berkdudukan sebagai investor pada badan usaha lain.

\section{B. Badan Usaha di Indonesia}

Menurut Chidir Ali menjelaskan tentang badan usaha dengan penekanan memiliki unsur-unsur sebagai berikut :13 1). Badan usaha merupakan perwujudan dan pengejawantahan organisasi perusahaan, yang memilik komponen bentuk cara kerja, bentuk wadah kerja dan bentuk / besar kecilnya tanggung jawab pengurus serta para anggota.; 2). Badan usaha menghasilkan laba yang diperoleh dari hasil pemasaran berupa barang dan atau jasa yang dihasilkan oleh suatu perusahaan.; 3). Suatu badan usaha yang merupakan perwujudan dari suatu perusahaan yang terorganisir.; 4). Badan usaha berbentuk abstrak (bahwa pada hakikatnya badan usaha merupakan organisasi dari suatu perusahaan, yang diketahui umum, dan untuk pembedanya teletak pada bentuk badan usaha sebagaimana yang tertulis didepan namanya seperti: CV. Fa. PT dan sebagainya. Sedangkan hal yang terlihat secara konkret dari suatu badan usaha adalah perusahaannya.

Pada sisi tentang apa yang dimaksud dengan perusahaan, Chidir Ali memberi penekanan bahwa perusahaan memiliki unsur-unsur sebagai berikut : 1). adalah suatu daya ikhtiar atau pekerjaan yang teratur dan dilaksanakan sebagai mata pencaharian sehari-hari, 2). bentuk yang dihasilkan oleh perusahaan berupa barang dan atau jasa yang selanjutnya dipasarkan oleh badan usaha, 3). bentuk konkret perusahaan terlihat seperti toko, restoran, bengkel, bioskop, hotel, persewaan gundang, tempat pemangkas rambut, tempat berobat umum dan sebagainya. ${ }^{14}$

Dalam peraturan perundang-undangan istilah perusahaan dijumpai dalam ketentuan Pasal 1 Undang-Undang Nomor 3 Tahun 1982 tentang Wajib Daftar Perusahaan, menyatakan bahwa perusahaan adalah :"setiap bentuk usaha yang menjalankan setiap jenis usaha yang bersifat tetap dan terus-menerus dan yang

${ }^{13}$ Chidir Ali. (2005). Badan Hukum. Bandung: Alumni, h. 107-108

${ }^{14}$ Ibid. 
didirikan, bekerja serta berkedudukan dalam wilayah Negara Republik Indonesia, untuk tujuan memperoleh keuntungan dan atau laba" ${ }^{15}$ Berdasarkan pada pengertian tersebut, maka ada dua unsur pokok yang terkandung dalam suatu perusahaan yaitu pertama, bentuk badan usaha yang berbadan hukum maupun tidak berbadan hukum, Kedua Jenis usaha bergerak dalam bidang bisnis, dijalankan secara terus menerus dan mencari keuntungan.

Dalam hukum perusahaan di Indonesia, badan usaha di klasifikasi dalam dua bentuk yaitu badan usaha bukan badan hukum dan bentuk badan usaha badan hukum. Bentuk badan usaha bukan badan hukum meliputi : Perusahaan Perorangan, Firma (Fa), Comanditter Vennootschap atau disebut Persekutuan komanditer (CV), Persekutuan Perdata (Maatschap), bentuk kegiatan usaha tersebut diatur dalam Kitab Undang-Undang Hukum Dagang (KUHD), dan selain itu terdapat juga badan usaha yang didirikan oleh perorangan perusahaan perseorangan atau pada umumnya disebut usaha dagang (UD). Sedangkan badan usaha yang berbadan hukum meliputi Perseroan Terbatas dan Koperasi. ${ }^{16}$ Selain itu dengan diterbitkannya UU No. 11 Tahun 2020 tentang Cipta Kerja diatur tentang Perseroan Terbatas Perseorangan. Berikut pendiri dari masing-masing badan usaha dimaksud :

\section{a. Pendirian Perusahaan Perorangan}

Perusahaan perorangan ini didirikan oleh satu orang, perusahaan perorangan belum diatur dalam undang-undang, tetapi eksistensinya diakui oleh pemerintah sebagaimana berdasarkan pada Undang-undang Nomor 3 Tahun 1982 tentang Wajib Daftar Perusahaan bahwa perusahaan yang berkedudukan di Indonesia wajib mendaftarkan perusahaannya. ${ }^{17}$

\section{b. Pendirian Firma (Fa)}

Firma (Fa) adalah persekutuan perdata yang didirikan untuk menjalankan perusahaan dengan nama bersama (Pasal $16 \mathrm{KUHD}$ ), adapun persekutuan perdata adalah perjanjian dengan mana dua orang atau lebih mengikatkan diri untuk menyetorkan sesuatu kepada pesekutuan dengan tujuan untuk memperoleh manfaat atau keuntungan (Pasal 1618 KUH Perdata). Pasal 16 KUHD menyatakan bahwa untuk menjalankan perusahaan dengan memakai nama bersama. Jelasnya jika beberapa orang mendirikan firma, maka firma itu harus memakai nama bersama. Dalam pengertian "nama bersama" itu bukan sekadar dalam arti dipergunakannya "suatu nama" untuk bersama tetapi lebih dari itu, yaitu nama para sekutu itulah yang dipergunakan untuk nama perusahaan. Setidak - tidaknya nama salah seorang sekutu. Sebab itulah acapkali timbul "Fa Jan De Boer \& Co" umpamanya, atau misalnya "Fa Hong \& Zoon" yang menunjukkan usaha bersama dari Tuan Hong bersama putranya. Mengapa demikian, karena menurut doktrinnya, persekutuan firma itu adalah asosiasi orang. ${ }^{18}$

\footnotetext{
${ }^{15}$ Pasal 1 UU No. 3 Tahun 1982 Tentang Wajib Daftar Perusahaan.

${ }^{16}$ Abdulkadir Muhammad, Hukum Perusahaan Indonesia, Bandung : PT. Citra Aditya Bhakti, 1999, h. 2

17 Pasal 7 Undang-Undang Nomor 3 Tahun 1982

${ }^{18}$ Rudhi Prasetya, Perseroan Terbatas Teori dan Praktik, Jakarta : Sinar Grafika, 2011, h. 12
} 
Persekutuan Komanditer (CV) di atur dalam Pasal 19 Kitab Undang-Undang Hukum Dagang (KUHD). Disebutkan bahwa persekutuan komanditer dibentuk dengan cara meminjamkan uang, yang didirikan oleh seseorang atau beberapa orang pesero yang bertanggung jawab secara tanggung renteng dan satu orang pesero atau lebih yang bertindak sebagai pemberi pinjaman uang. Pada beberapa referensi lain, pemberian pinjaman modal atau bisa disebut inbreng, dapat berbentuk selain uang, misalnya benda atau yang lainnya.

Berdasar ketentuan pasal tersebut diatas, maka di dalam CV terdapat dua hal unsur yaitu pesero yang bertanggung jawab secara tanggung renteng (pesero aktif atau pesero komplementer) dan pesero yang memberikan pinjaman uang (pesero pasif atau Pesero komanditer). Pesero aktif ini adalah orang yang mempunyai tanggung jawab penuh untuk menjalankan perusahaan dengan jabatan direktur. Sedang pesero pasif merupakan orang yang mempunyai tanggung jawab sebatas modal yang ditempatkan dalam perusahaan yaitu sebagai Pesero Komanditer.

\section{b. Pendirian Koperasi}

Koperasi, istilah koperasi berasal dari bahasa latin coopere atau corporation dalam bahasa Inggris. Secara etimologi koperasi berasal dari kata cooperation, co yang memiliki arti bersama dan operation artinya adalah bekerja atau berusaha. Sehingga cooperation adalah bekerja bersama-sama untuk kepentingan bersama. Oleh karena itu, koperasi adalah suatu perkumpulan yang beranggotakan orang-orang atau badan-badan yang memberikan kebebasan masuk dan keluar sebagai anggota, dengan bekerjasama secara kekeluargaan menjalankan usaha, untuk mempertinggi kesejahteraan jasmaniah para anggotanya. ${ }^{19}$

\section{c. Pendirian Perseroan Terbatas}

Berdasarkan pada Undang-Undang Nomor 40 Tahun 2007 Tentang Perseroan Terbatas, Perseroan Terbatas didefinisikan sebagai suatu badan hukum yang merupakan persekutuan modal, didirikan berdasarkan perjanjian, melakukan kegiatan usaha dengan modal dasar yang seluruhnya terbagi dalam saham, dan melalui persyaratan yang ditetapkan dalam Undang-undang ini serta peraturan perlaksanannya. ${ }^{20}$

Perseroan terbatas didirikan berdasarkan pada perjanjian para pendiri, yang pada awalnya merupakan aturan main yang mengatur hubungan internal antara para pendiri atau pemegang saham (setelah perseroan terbatas berbadan hukum), Direksi dan anggotanya, Dewan Komisaris dan para anggotanya. Akta tersebut harus dibuat dalam bentuk notariil, dan dikenal dengan nama akta pendirian perseroan terbatas. Sebagai suatu perjanjian perseroan terbatas yang didirikan berdasar pada kesepakatan dua atau lebih pihak, yakni baik dapat orang pribadi maupun badan hukum sebagaimana hal ini diatur dalam ketentuan Pasal 8 ayat (2) huruf a UU No. 40 Tahun 2007.

\section{d. Pendirian Perseroan Terbatas Perorangan}

\footnotetext{
19 Pasal 1 butir 1 UU No. 25 Tahun 1992 Tentang Perkoperaian

20 Gunawan Widjaja, Seri Pemahaman Perseroan Terbatas 150 Pertanyaan Tentang Perseroan Terbatas, Jakarta : Forum Sahabat, 2008, h. 2
} 
Aturan pendirian perseroan terbatas, diatur dalam UU No. 11 Tahun 2020 tentang Cipta Kerja, lahirnya undang-undang cipta kerja memberi kemudahan berusaha di Indonesia, pendirian PT dapat dilakukan oleh 1 (satu) orang saja, dan pendirian tidak perlu dengan membuat Akta pendirian, namun cukup dengan pernyataan pendirian perseroan yang disahkan secara elektronik oleh Menteri Hukum dan Hak Asasi Manusia. ${ }^{21}$ Dengan syarat perseorangan dimaksud adalah badan usaha perorangan yang memenuhi kriteria sebagai usaha mikro dan kecil. ${ }^{22}$ Dengan demikian lahirnya UU No. 11 Tahun 2020 Tentang Cipta Kerja di Indonesia terdapat 2 (dua) Perseroan Terbatas yakni 1). Perseroan Terbatas, dan, dan 2). Perseroan Terbatas Perseorangan. Yang menjadi pembeda dari Perseroan Terbatas tersebut adalah terletak dari pendiri Perseroan Terbatas, dan pada karakter khusus dari perseroan terbatas perorangan terletak pada karakter Usaha Mikro dan Kecil, sementara Perseroan Terbatas memiliki karakteristik di luar itu.

Karakteristik kegiatan usaha mikro dan kegiatan usaha kecil dibedakan dari sisi besarnya kekayaan yang digunakan untuk kegiatan usaha tersebut, dengan kriteria jumlah kekayaan sebagai berikut : pada kegiatan usaha mikro memiliki kekayaan bersih paling banyak Rp. 50.000.000,00 (Lima puluh juta rupiah), kekayaan ini tidak termasuk nilai tanah dan bangunan tempat dilakukannya usaha atau memiliki hasil penjualan per tahun paling banyak Rp. 300.000 .000 (tiga ratus juta rupiah). Sedangkan kriteria usaha kecil memiliki kekayaan bersih lebih dari Rp. 50.000.000,00 (lima puluh juta rupiah) sampai dengan paling banyak Rp. 500.000.000,00 (lima ratus juta rupiah) tidak termasuk tanah dan bangunan tempat usaha; atau memiliki hasil penjualan thunan lebih dari Rp. 300.000.000,00 (tiga ratus juta rupiah) sampai dengan paling banyak Rp. 2.500.000.000,00 (dua milyar lima ratus juta rupiah). ${ }^{23}$

Sementara menurut Badan Pusat Statistik (BPS), standar definisi tentang usaha Mikro dan Kecil, BPS membedakan mengolongkannya berdasarkan pada jumlah tenaga kerja yang dimiliki oleh suatu badan usaha, yang pertama adalah industri rumah tangga apabila memiiki tenaga kerja antara 1 sampai 4 orang. Dan kedua adalah industri kecil dengan jumlah tenaga kerja antara 5 sampai dengan 9 orang, ketiga disebut dengan industri sedang/menengah apabila memiliki tenaga kerja antara 10 hingga 99 orang, dan yang ke empat, industri besar apabila memiliki jumlah tenaga kerja lebih dari 100 orang. ${ }^{24}$

\section{Undang-Undang Lain Yang Mengatur Yayasan Sebagai Badan Penyelenggara Suatu Kegiatan.}

Undang-undang yang memberi legalitas peran Yayasan dalam mensejaterakan masyarakat, di temukan dalam Undang-Undang Republik Indonesia Nomor 44 Tahun

${ }^{21}$ Pasal 153A ayat (2) Bagian kelima Perseroan Terbatas, UU No. 11 Tahun 2020 Tentang Cipta Kerja.

22 Pasal 1 ayat (1) dalam Bagian kelima Perseroan Terbatas, UU No. 11 Tahun 2020 Tentang Cipta Kerja.

${ }^{23}$ Pasal 6 ayat (1) dan (2) UU No. 20 Tahun 2008 Tentang Usaha Mikro, Kecil dan Menengah

24 Rachmawan Budiarto, dkk, Pengembangan UMKM Antara Konseptual dan Pengalaman Praktis, Yogyakarta : Gadjah Mada University Press, 2015, h.2 
2009 Tentang Rumah Sakit. Rumah Sakit adalah institusi pelayanan kesehatan yang menyelenggarakan pelayanan kesehatan perorangan secara paripurna yang menyediakan pelayanan rawat inap, rawat jalan, dan gawat darurat, ${ }^{25}$ yang diselenggarakan berasaskan Pancasila dan didasarkan kepada nilai kemanusiaan, etika dan profesionalitas, manfaat, keadilan, persamaan hak dan anti diskriminasi, pemerataan, perlindungan dan keselamatan pasien, serta mempunyai fungsi sosial. ${ }^{26}$ Rumah sakit berdasarkan pengelolaannya dapat dibagi menjadi Rumah Sakit Publik dan Rumah Sakit privat.27 Rumah sakit publik dapat dikelola oleh Pemerintah, Pemerintah Daerah, dan badan hukum yang bersifat nirlaba. ${ }^{28}$ Badan hukum nirlaba dimaksud adalah badan hukum yang sisa hasil usahanya tidak dibagikan kepada pemilik, melainkan digunakan untuk meningkatkan pelayanan yaitu antara lain Yayasan, Perkumpulan dan Perusahaan Umum. ${ }^{29}$

Rumah sakit privat dikelola oleh badan hukum dengan tujuan profit yang berbentuk Perseroan Terbatas atau Perseroan. ${ }^{30}$ Berdasarkan pada UU RI No. 44 Tahun 2009 tentang Rumah Sakit, badan hukum Yayasan sebagai pengelola Rumah Sakit dengan mendirikan badan usaha berbentuk Perseroan Terbatas.

Undang-Undang Republik Indonesia Nomor 13 Tahun 2011 Tentang Penanganan Fakir Miskin. Di jelaskan bahwa yang dimaksud kategori fakir miskin menurut undangundang ini yaitu seseorang yang tidak memiliki sumber mata pencaharian sama sekali, atau seseorang yang memiliki sumber pencaharian namun sumber pencaharian yang dimilikinya tidak mampu untuk mencukupi kebutuhan dasarnya secara layak baik bagi kehidupan dirinya sendiri maupun keluarganya. ${ }^{31}$ Dan yang dimaksud penanganan fakir miskin dari undang-undang ini yaitu tentang upaya yang dijalankan secara terarah, terpadu dan secara berelanjutyan yang kesemuanya itu dilakukan oleh Pemerintah, Pemerintah Daerah, atau masarakat, dalam bentuk berupa kebijakan, progaram dan kegiatan pemberdayaan, pemberian pendampian, serta pemberian fasilitas guna memenuhi kebutuhan dasar setiap warga negara.32 Penanganan kepada fakir miskin diselenggarakan berdasar pada asas kemanusiaan, keadilan sosial, nondiskriminasi, kesejahteraan, kesetiakawanan dan pemberdayaan. ${ }^{33}$ Peran masyarakat dalam penanganan fakir miskin, meliputi peranannya sebagai penyelenggara dan pengawasan penanganan fakir miskin, dan dilakukan oleh : badan usaha, organisasi kemasyarakatan, perseorangan, keluarga, kelompok, organiasi sosial, yayasan, lembaga swadaya masyarakat, organisasi profesi, dan atau pelaku usaha. ${ }^{34}$

${ }^{25}$ Pasal 4 UU Ormas 5 Pasal 9 UU Ormas 6 Pasal 1 Butir 1 UU RI No. 44 Tahun 2009 Tentang Rumah Sakit

${ }^{26}$ Pasal 2 Butir 1 UU RI No. 44 Tahun 2009 Tentang Rumah Sakit

27 Pasal 20 Ayat (1) UU RI No. 44 Tahun 2009 Tentang Rumah Sakit

28 Pasal 20 Ayat (2) UU RI No. 44 Tahun 2009 Tentang Rumah Sakit

${ }^{29}$ Penjelasan Pasal 20 Ayat (2) UU RI No. 44 Tahun 2009 Tentang Rumah Sakit

${ }^{30}$ Pasal 21 UU RI No. 44 Tahun 2009 Tentang Rumah Sakit

${ }^{31}$ Pasal 1 Butir 1 UU RI No. 13 Tahun 2011 Tentang Penanganan Fakir Miskin

32 Pasal 1 butir 2 UU RI No. 13 Tahun 2011 tentang Penanganan Fakir Miskin

33 Pasal 2 UU RI No. 13 Tahun 2011 tentang Penanganan Fakir Miskin

34 Pasal 41 ayat (1) UU RI No. 13 Tahun 2011 tentang Penanganan Fakir Miskin 
Undang-Undang Republik Indonesia Nomor 11 Tahun 2009 Tentang Kesejahteraan Sosial. Kesejahteraan sosial adalah kondisi terpenuhinya kebutuhan material, spiritual, dan sosial warga negara agar dapat hidup secara layak dan mampu mengembangkan diri, serta dapat melaksanakan fungsi sosialnya. ${ }^{35}$ Penyelenggaraan kesejahteraan sosial ditujukan bagi kepada perseorangan, keluarga, suatu kelompok; dan/atau kepada masyarakat. Dan diutamakan bagi mereka yang memiliki kehidupan yang tidak layak secara kemanusiaan, dengan memiliki kriteria masalah sosial, meliputi hal-hal berikut : a. kemiskinan; b. ketelantaran; c. kecacatan; d. keterpencilan; e. ketunaan sosial dan penyimpangan perilaku; f. korban bencana; dan/atau g. korban tindak kekerasan, eksploitasi dan diskriminasi. ${ }^{36}$

Penyelenggaraan kesejahteraan sosial diselenggarakan berdasarkan pada asas kesetiakawanan, keadilan, kemanfaatan, keterpaduan, kemitraan, keterbukaan, akuntabilitas, partisipasi, professional dan keberlanjutan. ${ }^{37}$ Merupakan upaya yang terarah terpadu dan berkelanjutan yang dilakukan oleh Pemerintah, Pemerintah daerah, dan masyarakat, dengan bentuk pemberian pelayanan sosial untuk memenuhi kebutuhan dasar setiap warga negara, meliputi hal-hal berikut yaitu 1). rehabilitasi sosial, 2). jamian sosial, 3). pemberdayaan sosial, dan 4). perlindungan sosial. ${ }^{38}$ Lembaga kesejahteraan sosial yang didirikan oleh masyarakat untuk menyelenggarakan kesejahteraan sosial tersebut dilakukan oleh organisasi berbadan hukum atau tidak berbadan hukum, ${ }^{39}$ dalam undang-undang ini Yayasan dikategorikan sebagai organisasi berbadan hukum. Undang-undang RI Nomor 20 Tahun 2003 Tentang Sistem Pendidikan Tinggi. "Pendidikan adalah usaha sadar dan terencana untuk mewujudkan suasana belajar dan proses pembelajaran agar peserta didik secara aktif mengembangkan potensi dirinya untuk memiliki kekuatan spiritual keagamaan, pengendalian diri, kepribadian, kecerdasan, akhlak mulia, serta keterampilan yang diperlukan dirinya, masyarakat, bangsa dan negara". ${ }^{40}$ Pembagian kelompok layanan pendidikan penyelenggaraan satuan pendidikan tersebut terbagi atas pendidikan jalur formal, pendidikan jalur nonformal, dan pendidikan jalur in formal pada setiap jenjang dan jenis pendidikan. ${ }^{41}$

Undang-undang Republik Indonesia Nomor 12 Tahun 2012 Tentang Pendidikan Tinggi. "Pendidikan Tinggi adalah jenjang pendidikan setelah pendidikan menengah yang mencakup program diploma, program sarjana, program magister, program doktor, dan program profesi, serta program spesialis, yang diselenggarakan oleh perguruan tinggi berdasarkan kebudayaan bangsa Indonesia".42 Satuan pendidikan yang menyelenggarakan pendidikan tinggi disebut Perguruan Tinggi. Perguruan tinggi berdasarkan pendiri dan penyelenggaranya dibagi atas peguruan tinggi negeri dan

\footnotetext{
${ }^{35}$ Pasal 1 butir 1 UU RI No. 11 tahun 2009 Tentang Kesejahteraan Sosial.

36 Pasal 5 ayat (1) dan (2) UU RI No. 11 Tahun 2009 Tentang Kesejahteraan Sosial.

${ }^{37}$ Pasal 2 UU RI No. 11 Tahun 2009 Tentang Kesejahteraan Sosial.

${ }^{38}$ Pasal 1 ayat (2) UU RI No. 11 Tahun 2009 Tentang Kesejahteraan Sosial.

${ }^{39}$ Pasal 1 butir 7 UU RI No. 11 Tahun 2009 Tentang Kesejahteraan Sosial.

40 Pasal 1 butir 1 UU RI No. 20 Tahun 2003 Tentang Sistem Pendidikan Tinggi

${ }^{41}$ Pasal butir 10 UU RI No. 20 Tahun 2003 Tentang Sistem Pendidikan Tinggi

${ }^{42}$ Pasal 1 butir 2 UU RI No. 12 Tahun 2012 Tentang Pendidikan Tinggi
} 
perguruan tinggi swasta, perguruan tinggi Negeri didirikan dan diselenggarakan oleh Pemerintah, sedangkan Perguruan Tinggi Swasta didirikan dan diselenggarakan oleh masyarakat. ${ }^{43}$ Didirikan oleh masyarakat melalui badan hukum berprinsip nirlaba seperti yayasan, perkumpulan, dan badan hukum yang lain sesuai peraturan perundangundangan. ${ }^{4}$

\section{Bentuk Badan Usaha yang Dapat Didirikan oleh Yayasan dan Legalitas Kegiatan Usaha Yayasan yang Dijalankan atas Nama Para Organ Yayasan}

Yayasan merupakan badan hukum yang didirikan atas kekayaan yang dipisahkan dari pemiliknya dan diperuntukkan untuk maksud dan tujuan Yayasan, oleh karena itu merujuk pada teori kekayaan bertujuan, tidak ada subyek hukum sebagai pemilik dari kekayaan suatu Yayasan kecuali Yayasan itu sendiri. Sebagaimana hal tersebut ditegaskan dalam ketentuan Pasal 1 butir 1 UU No. 16 Tahun 2001 juncto UU No. 28 Tahun 2004 Tentang Perubahan Atas UU No. 16 Tahun 2001 tentang Yayasan yaitu menyatakan sebagai berikut: "Yayasan adalah badan hukum yang terdiri atas kekayaan Yayasan dipisahkan dan diperuntukan untuk mencapai tujuan tertentu dibidang sosial, keagamaan, dan kemanusiaan yang tidak mempunyai anggota". ${ }^{45}$

Kemajuan dan peningkatan pembangunan nasional pada umumnya dan perkembangan kegiatan ekonomi pada khsusunya yang menyebabkan berkembangnya dunia usaha dan perusahaan. Suatu perusahan memerlukan adanya legalitas perusahaan yang merupakan sumber informasi resmi untuk semua pihak yang berkepentingan menganai identitas dan hal-hal yang menyangkut dunia usaha dan perusahaan yang didirikan, bekerja serta berkedudukan di wilayah Negara Republik Indonesia. Legalitas suatu perusahaan atau badan usaha adalah merupakan unsur yang terpenting, karena legalitas merupakan jati diri yang melegalkan atau mengesahkan suatu badan usaha di tengah masyarakat.

Dengan kata lain, legalitas perusahaan harus sah menurut undang-undang dan peraturan, dimana perusahaan tersebut dilindungi atau dipayungi dengan berbagai dokumen hingga sah di mata hukum dari pemerintahan yang berkuasa saat itu. keberlangsungan suatu usaha dipengaruhi oleh berbagai faktor, salah satunya adalah keberadaan unsur legalitas dari usaha tersebut. Dan dalam suatu usaha, faktor legalias ini berwujud pada kepemilikan izin usaha yang dimiliki. Contoh dokumen yang mendukung sahnya perusahaan tersebut adalah antara lain : akta pendirian perusahaan tersebut oleh notaris dan diumumkan di lembaran negara, nomor pokok wajib pajak perusahaan, surat izin usaha, surat izin gangguan atau HO (hinderordonnantie), izin lokasi, izin lingkungan dan banyak izin-izin lainnya yang sesuai bidang usahanya masingmasing. Perusahaan sebagai wahana pembangunan perekonomian diatur di dalam Kitab Undang-Undang Hukum Perdata, Kitab Undang-Undang Hukum Dagang dan peraturan perundang - undangan.

${ }^{43}$ Pasal 1 butir 6, 7, 8 UU RI No. 12 Tahun 2012 Tentang Pendidikan Tinggi

${ }^{44}$ Pasal 60 ayat (2) dan (3) UU RI No. 12 Tahun 2012 Tentang Pendidikan Tinggi

45 Undang-Undang Nomor 16 Tahun 2001, Pasal 1 Butir 1. 
Bahwa berdasarkan pada uraian yang telah di jelaskan diatas, maka dapat ditarik kesimpulan bahwa suatu yayasan yang mendirikan kegiatan usaha dengan tujuan agar badan usaha yang didirikan tersebut dapat menghasilkan keuntungan yang selanjutnya dapat digunakan sebagai penunjang operasional yayasan dalam mencapai maksud dan tujuan didirikannya suatu Yayasan, belum mendapatkan pengaturan yang memadahi dan pengaturan yang dapat dengan mudah dilaksanakan oleh Yayasan. Sebagaimana fakta dilapangan Yayasan cenderung mendirikan badan usaha melalui nama-nama para organ Yayasan hal ini terjadi karena dirasa akan lebih mudah dan biaya ringan jika dibandingkan dengan mendirikan koperasi atupun perseroan terbatas. Kekayaan Yayasan yang digunakan untuk mendirikan badan usaha dengan menggunakan nama salah satu organ Yayasan sangat beresiko bagi Yayasan kehilangan kekayaannya, oleh karenanya pengaturan hukum tentang bentuk badan usaha yang dapat didirikan oleh Yayasan masih perlu untuk diatur kembali, pada bentuk badan usaha yang lebih bisa sesuai dengan karakteristik dan sisi kemampuan finansial yayasan.

\section{PENUTUP}

Badan usaha yang dapat didirikan oleh Yayasan meliputi berbentuk PT dan Koperasi, selebihnya tidak dapat didirikan oleh Yayasan karena seperti UD, CV, Fa pada prinsipnya hanya dapat didirikan oleh orang per orangan, sementara Yayasan merupakan badan hukum. Selain itu diluar yang diatur dalam hukum perusahaan, Yayasan dapat mendirikan kegiatan usaha berdasar pada undang-undang yang menyatakan Yayasan sebagai badan penyelenggara, misalnya bidang kesehatan dan pendidikan. Legalitas bagi badan usaha yang didirikan atas nama salah seorang organ Yayasan dengan menggunakan kekayaan Yayasan, maka legalitas kepemilikan badan usaha tersebut terletak nama orang yang tercantum dalam akta pendirian badan usaha tersebut dan bukan yayasan.

Perlu diatur payung hukum bentuk badan usaha yang lebih fleksibel dan tidak memberatkan Yayasan yakni semacam Perseroan Terbatas Perorangan namun khusus bagi yayasan, sehingga dengan kemudahan berusaha bagi Yayasan, selain dapat meningkatnya sumber pendapatan dan menciptakan kemandirian Yayasan, juga untuk mengatasi kebocoran kekayaan Yayasan sebagaimana amanat Pasal 5 Undang-undang Yayasan. 


\section{DAFTAR PUSTAKA}

Abdulkadir Muhammad. (1999). Hukum Perusahaan Indonesia, Bandung: PT. Citra Aditya Bhakti.

Chidir Ali. (2005). Badan Hukum. Bandung: Alumni.

Gunawan Widjaja. (2008). Seri Pemahaman Perseroan Terbatas 150 Pertanyaan Tentang Perseroan Terbatas. Jakarta: Forum Sahabat.

Kasiani. (2019). Rekonsepsi Penggabungan Yayasan Pendidikan Tinggi dalam Perspektif UU RI No. 28 Tahun 2004 tentang Perubahan Atas UU RI Nomor 16 Tahun 2001 tentang Yayasan. Disertasi Program Doktor Ilmu Hukum Fakultas Hukum Universitas Brawijaya.

Rachmawan Budiarto, dkk. (2015). Pengembangan UMKM Antara Konseptual dan Pengalaman Praktis. Yogyakarta: Gadjah Mada University Press.

Rudhi Prasetya. (2011). Perseroan Terbatas Teori dan Praktik. Jakarta : Sinar Grafika.

UUD Negara Republik Indonesia 1945

UU RI No. 16 Tahun 2001 tentang Yayasan.

UU RI No. 28 Tahun 2004 tentang Perubahan Atas UU No. 16 Tahun 2001 tentang Yayasan

UU RI No. 3 Tahun 1982 tentang Wajib Daftar Perusahaan

UU RI No. 44 Tahun 2009 tentang Rumah Sakit

UU RI No. 13 Tahun 2011 tentang Penanganan Fakir Miskin

UU RI No. 11 tahun 2009 tentang Kesejahteraan Sosial

UU RI No. 20 Tahun 2003 tentang Sistem Pendidikan Tinggi

UU RI No. 12 Tahun 2012 tentang Pendidikan Tinggi

UU RI No. 40 Tahun 2007 tentang Perseroan Terbatas

UU RI No. 20 Tahun 2008 tentang Usaha Mikro, Kecil, dan Menengah

UU RI No. 11 Tahun 2011 tentang Cipta Kerja 